\title{
Halimium as an ectomycorrhizal symbiont: new records and an appreciation of known fungal diversity
}

\author{
Marco Leonardi ${ }^{1}$ - Ariadne Nóbrega Marinho Furtado ${ }^{2} \cdot$ Ornella Comandini $^{3} \cdot$ József Geml $^{4} \cdot$ Andrea C. Rinaldi $^{5}$ (I)
}

Received: 2 July 2020 /Revised: 15 October 2020 / Accepted: 19 October 2020

(C) The Author(s) 2020

\begin{abstract}
Halimium is a genus of Cistaceae, containing a small group of shrub species found in open vegetation types and in degraded forest patches throughout the western and central Mediterranean region. We recently described the morpho-anatomical features of the ectomycorrhizae formed by Scleroderma meridionale on Halimium halimifolium, but the mycorrhizal biology of this host plant genus is still largely unexplored. Here, we report new data on the ectomycorrhizal fungal symbionts of Halimium, based on the collection of sporocarps and ectomycorrhizal root tips in pure stands occurring in Sardinia, Italy. To obtain a broader view of Halimium mycorrhizal and ecological potential, we compiled a comprehensive and up-to-date checklist of fungal species reported to establish ectomycorrhizae on Halimium spp. on the basis of field observations, molecular approaches, and mycorrhiza synthesis. Our list comprises 154 records, corresponding to 102 fungal species and 35 genera, revealing a significant diversity of the Halimium ectomycorrhizal mycobiota. Key ectomycorrhizal genera like Russula, Lactarius/Lactifluus, Amanita, Inocybe, and Cortinarius account for more than half of all mycobionts. A large proportion of Halimium fungal species are shared with other host plants in various ecological settings, suggesting a critical role of common mycorrhizal networks in the function played by this shrub in various Mediterranean ecosystems.
\end{abstract}

Keywords Cistaceae $\cdot$ Ecological networks $\cdot$ Ectomycorrhiza $\cdot$ Fungal communities $\cdot$ Maquis shrubland

\section{Introduction}

Shrublands occupy a specific niche in the Mediterranean biome, with an increasingly appreciated ecological function. In particular, plants occurring in this peculiar environment improve water and light regime, protect soil from erosion, and

Section Editor: Dominik Begerow

Andrea C. Rinaldi

rinaldi@unica.it

1 Department of Life, Health and Environmental Sciences, University of L'Aquila, I-67100 Coppito, AQ, Italy

2 Departamento de Botânica, Campus Universitário Reitor João David Ferreira Lima Centro de Ciências Biológicas, Universidade Federal de Santa Catarina, Trindade, Florianópolis, SC 88040-960, Brazil

3 Department of Life Sciences and the Environment, University of Cagliari, I-09042 Monserrato, CA, Italy

4 MTA-EKE Lendület Environmental Microbiome Research Group, Eszterházy Károly University, Leányka u. 6., Eger H-3300, Hungary

5 Department of Biomedical Sciences, University of Cagliari, I-09042 Monserrato, CA, Italy desertification, and act as "nurse" species for tree seedlings, thus favoring the establishment of late-successional species (https://php.radford.edu/ swoodwar/biomes/?page_id=98). To perform such tasks, the shrubs and small trees that integrate this vegetation system developed adaptations to withstand adverse and stressful conditions such as drought and fire (Rundel and Cowling 2013). The presence of a large number of ectomycorrhizal fungi, mainly associated with Cistaceae Juss., is another common trait of Mediterranean shrublands. The role played by ectomycorrhizal fungi in optimizing plant fitness and increasing nutrients' availability in a wide range of terrestrial ecosystems, especially where cold and dry conditions limit decomposition, is largely appreciated (Smith and Read 1997). Cistus is the dominant ectomycorrhizal host plant in Mediterranean shrublands. Over 250 fungal species belonging to 40 genera have been reported to be associated with Cistus, with 35 host-specific species; members of the Cortinariaceae and Russulaceae make up the most of both generalist and Cistus-specific mycobionts (Comandini et al. 2006; Loizides 2016).

The genus Halimium (Dunal) Spach belongs to the Cistaceae (Page 2017), with 13 accepted species of evergreen 
or semi-deciduous small-to-large shrubs (http://www. theplantlist.org/1.1/browse/A/Cistaceae/Halimium/). However, these include $H$. brasiliense (Lam.) Grosser that is considered by other sources a synonym of Crocanthemum brasiliensis Spach and that has a disjunct distribution (in the New World) with respect to all other known species of Halimium (https://www.gbif.org/species/3596090), and Halimium $\times$ pauanum Font Quer, a naturally occurring hybrid between $H$. lasiocalycinum (Boiss. \& Reuter) Engler \& Pax and H. lasianthum (Lam.) Spach (Soriano 2008). A new species, $H$. voldii Kit Tan, Perdetz. \& Raus has been recently described from Greece (Greuter and Raus 2000); however, both the status of this taxon and that of $H$. syriacum $\mathrm{K}$. Koch, reported from subalpine levels in Lebanon and Syria, are still unresolved. Halimium is closely related to Cistus; some botanists in the past have considered Halimium species as belonging to Cistus (e.g., Demoly 2006), but the most recent molecular phylogenetic analyses have clearly shown the two genera as distinct (Guzmán and Vargas 2005, 2009; Civeyrel et al. 2011). The two genera overlap largely in distribution within the Mediterranean basin although Halimium is restricted to the western part of the floristic region (Civeyrel et al. 2011) (Fig. 1). Halimium species occur usually in open vegetation types, like matorral shrublands and garrigues, but they can also been found in degraded forest patches, at the verges of woods, abandoned fields, pasturelands, and on coastal sandy areas and dry dunes (Zunzunegui et al. 2002, 2009).

The mycorrhizal biology of Halimium is poorly known. The genus may form ectomycorrhizae and possibly vesicular arbuscular mycorrhizae (Camprubi et al. 2011; Buscardo et al. 2012; Beddiar et al. 2015). To expand the current knowledge of mycorrhizal interactions of Halimium, we started a research program focusing on the isolation and full characterization of the ectomycorrhizae formed by the fungal symbionts associated with Halimium spp. We recently described, for the first time, the morphoanatomical features of an ectomycorrhiza on Halimium, formed by Scleroderma meridionale Demoulin \& Malençon on Halimium halimifolium (L.) Willk. (Leonardi et al. 2018). In the current paper, we report new data on Halimium mycobionts, as observed in pure stands occurring in Sardinia, Italy, through both sporocarps and ectomycorrhizal root tip collections. Also, we provide a comprehensive and up-to-date checklist of fungal species reported to establish ectomycorrhizae on Halimium spp. on the basis of field observations, molecular approaches, and mycorrhiza synthesis, a type of information that is widely dispersed in the mycological literature, with no specific account existing on the topic. The data presented here reveal a high diversity of the Halimium ectomycorrhizal mycobiota.

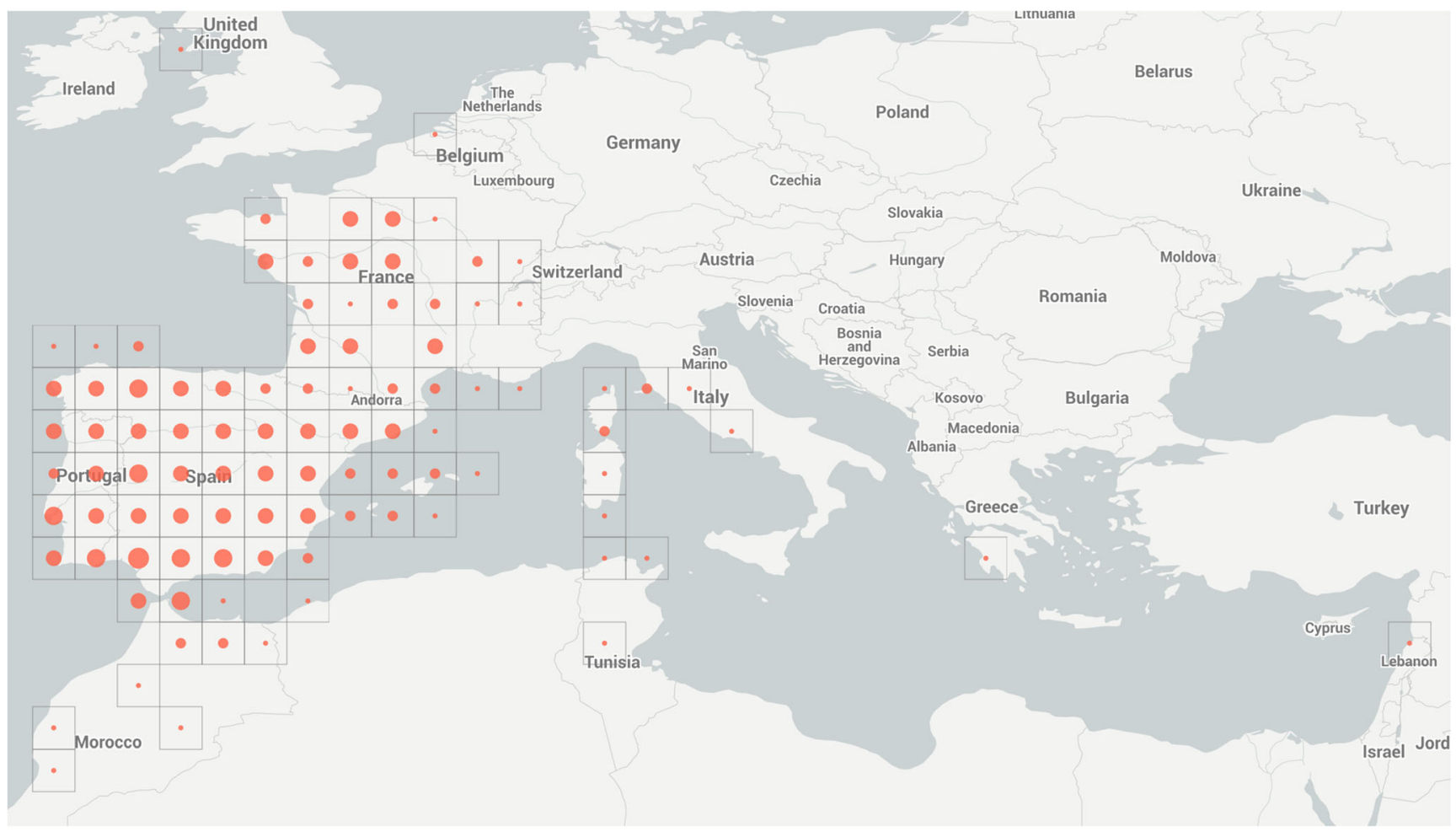

Fig. 1 Distribution map of Halimium spp. Occurrence data from the Global Biodiversity Information Facility (https://www.gbif.org/) 


\section{Materials and methods}

\section{Collecting site and fungal sampling}

Sporocarps of ectomycorrhizal fungi were harvested in a costal sandy area (from $39^{\circ} 15^{\prime} 17.42^{\prime \prime} \mathrm{N}, 8^{\circ} 24^{\prime} 32.75^{\prime \prime} \mathrm{E}$ to $39^{\circ} 15^{\prime} 46.07^{\prime \prime} \mathrm{N}, 8^{\circ} 24^{\prime} 46.89^{\prime \prime} \mathrm{E}$ and from 58 to $123 \mathrm{~m}$ asl) close to Gonnesa, about $70 \mathrm{~km}$ west of Cagliari, Sardinia, Italy. Collection surveys were conducted weekly during growing season (October-January) and monthly during the rest of the year, from 2015 through 2019. Sporocarps were photographed in situ and identified on the basis of published descriptions of macroscopic and microscopic characters. Fungal species names retrieved from literature were verified for nomenclatural and taxonomic synonyms in Index Fungorum (http://www. indexfungorum.org) and MycoBank (http://www. mycobank.org) and current names adopted. The collection site is characterized by extended stands $H$. halimifolium (Fig. 2) that here occurs practically in pure form. No other potential ECM host plants are present on the site, with the exception of a few scattered Cistus salviifolius L. shrubs. For ectomycorrhizae, 40 soil cores (about $20 \times$ $20 \times 20 \mathrm{~cm}$ ) were excavated randomly in proximity of Halimium shrubs (not underneath sporocarps), at least $5 \mathrm{~m}$ apart from each other. Soil cores were immersed overnight in water, and ectomycorrhizal roots were carefully separated under a dissecting microscope. Ectomycorrhizae were classified into morphotypes following the methods and indications of Agerer (1991), and several tips for each type were immediately transferred into $90 \% \mathrm{EtOH}$ and stored at $-20^{\circ} \mathrm{C}$ for subsequent DNA analysis or fixed in $2.5 \%(v / v)$ glutaraldehyde in $10 \mathrm{mM}$ Na-phosphate buffer ( $\mathrm{pH}$ 7.2) for morpho-anatomical description of characterizing features. Reference materials for sporocarps and ectomycorrhizae are deposited in CAG, at the collection of the Department of Biomedical Sciences, University of Cagliari, Cagliari, Italy.

\section{Molecular characterization of the fungi}

Identification of sporocarps and ectomycorrhizae using a molecular approach was based on PCR amplification and sequencing of the complete internal transcribed spacer (ITS) regions in nuclear ribosomal DNA (Gardes and Bruns 1993). Genomic DNAs of the sporocarps were isolated from $20 \mathrm{mg}$ of each dried sample using DNeasy Plant Mini Kit (Qiagen, Hilden, Germany), and the ITS amplifications were performed following the protocol reported by Leonardi et al. (2005). A direct PCR approach was applied to identify ectomycorrhizal tips isolated from soil samples as described by Iotti and Zambonelli (2006). Three ectomycorrhizal tips were selected as PCR targets and directly amplified using ITS1F/ITS4 primer pairs (White et al. 1990; Gardes and Bruns 1993). Two microliters of $20 \mathrm{mg} / \mathrm{ml}$ BSA (bovine serum albumin) solution (Fermentas, Vilnius) was added to each reaction tube to prevent PCR inhibition (Leonardi et al. 2013). The amplified products were purified using the QIAquick PCR Purification Kit (Qiagen, Milan, Italy) and sequenced by Eurofins Genomics service (Ebersberg, Germany). Sequence-based fungal identification was performed following the indications and recommendations reported in Hofstetter et al. (2019). Sequences of sporocarps and ectomycorrhizae are deposited in GenBank (https://www. ncbi.nlm.nih.gov/genbank/) under accession numbers specified in Table 1. In selected cases, to confirm the identity of the host shrub roots, the plastid trnL region of ECM root tip DNA was amplified using primer pairs trnC/ trnD following Tedersoo et al. (2008). In these cases, the chloroplast trnL region obtained by PCR amplification of DNA extract from $H$. halimifolium leaves was used as positive control.

\section{Compiling the list of records}

Data on the association between Halimium spp. and ectomycorrhiza-forming fungi presented here are largely
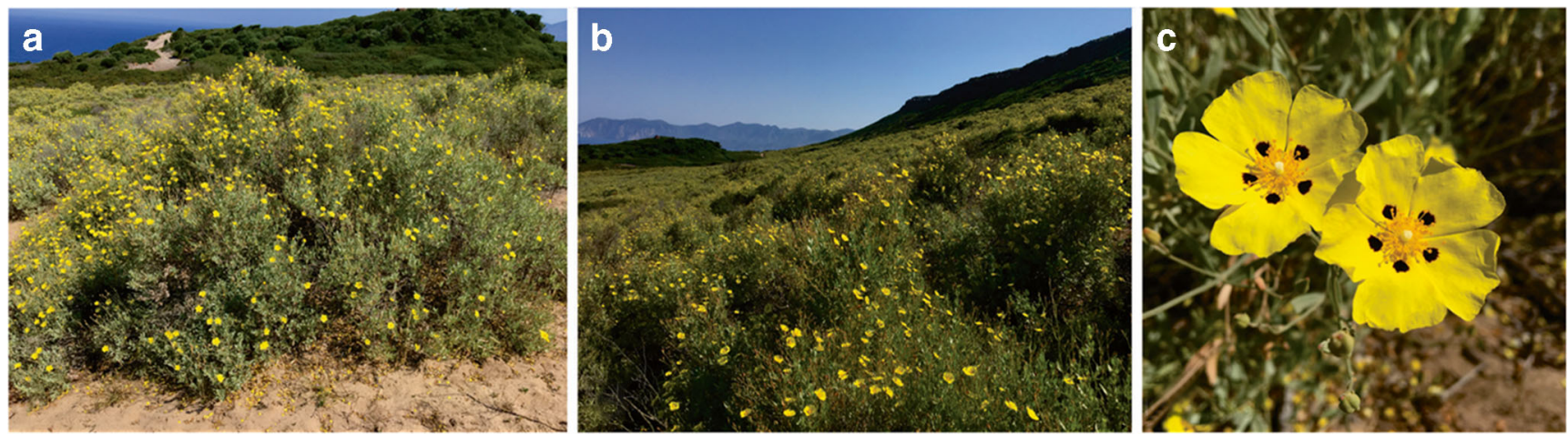

Fig. 2 Halimiun halimifolium, Cistaceae, in southwestern Sardinia. a Plant in blossom. b View of ECM collection stand. c Flower close-up 
Table 1 Ectomycorrhizal fungi reported to be associated with Halimium spp.

\begin{tabular}{|c|c|c|c|}
\hline Species & Host (Halimium) & Reference & Sequence \\
\hline \multicolumn{4}{|l|}{ Ascomycota } \\
\hline \multirow[t]{3}{*}{ Cenococcum geophilum Fr. } & $\begin{array}{l}\text { H. lasianthum, } \\
\text { H. ocymoides }\end{array}$ & Buscardo et al. 2012 (ECM) & HQ625444 \\
\hline & H. lasianthum & Santolamazza-Carbone et al. 2019 (ECM) & KY595999 \\
\hline & H. halimifolium & This study (ECM) & \\
\hline Terfezia boudieri Chatin $^{\mathrm{a}}$ & H. halimifolium & Chevalier 2014 & \\
\hline $\begin{array}{l}\text { Terfezia dunensis Ant. Rodr., Cabero, Luque \& } \\
\text { Morte }\end{array}$ & H. halimifolium & Crous et al. 2019 & MN438324 \\
\hline \multirow[t]{2}{*}{ Terfezia spp. } & H. halimifolium & Chatin 1891 & \\
\hline & H. halimifolium & Olaizola Suárez et al. 2012 & \\
\hline Terfezia sp. 1 & H. ocymoides & Buscardo et al. 2012 (ECM) & HQ625472 \\
\hline Terfezia sp. 2 & H. lasianthum & Buscardo et al. 2012 (ECM) & HQ625473 \\
\hline Tuber oligospermum Tul. \& C. Tul. (Trappe) ${ }^{\mathrm{b} \#}$ & H. halimifolium & This study $(\mathrm{ECM})$ & MT594491 \\
\hline \multicolumn{4}{|l|}{ Basidiomycota } \\
\hline $\begin{array}{l}\text { Alessioporus ichnusanus (Alessio, Galli \& Littini) } \\
\text { Gelardi, Vizzini \& Simonini }^{\#}\end{array}$ & H. halimifolium & This study & MT594492 \\
\hline Amanita cistetorum Contu \& Pacioni* & H. halimifolium & Moreau et al. 2007a, Moreau et al. 2007b & \\
\hline \multirow[t]{2}{*}{ Amanita citrina (Schaeff.:Fr.) Pers. } & H. halimifolium & Moreau et al. $2007 \mathrm{a}$ & \\
\hline & H. ocymoides & Buscardo et al. 2012 (ECM) & HQ625456 \\
\hline Amanita curtipes E.-J. Gilbert f. curtipes ${ }^{\#}$ & H. halimifolium & Moreau et al. 2007a & \\
\hline Amanita gilbertii Beauseign ${ }^{\#}$ & H. halimifolium & This study & MT594493 \\
\hline Amanita gracilior Bas \& Honrubia & Halimium sp. & Moreno-Arroyo 2004 & \\
\hline Amanita malleata (Piane ex Bon) Contu & H. halimifolium & Taudiere et al. 2015 & \\
\hline $\begin{array}{l}\text { Amanita muscaria var. inzengae Neville \& } \\
\text { Poumarat }\end{array}$ & H. halimifolium & Moreau et al. 2007a & \\
\hline \multirow[t]{2}{*}{ Amanita pantherina (D.C.:Fr.) Krombh ${ }^{\#}$} & H. halimifolium & Moreau et al. $2007 \mathrm{a}$ & \\
\hline & H. halimifolium & This study & MT594494 \\
\hline Amanita ponderosa Malençon \& R. Heim ${ }^{\#}$ & Halimium sp. & Moreno-Arroyo 2004 & \\
\hline Amanita rubescens (Pers.:Fr.) Gray ${ }^{\#}$ & Halimium sp. & Moreno-Arroyo 2004 & \\
\hline Amanita torrendii Justo & Halimium sp. & Moreno-Arroyo $2004^{\mathrm{c}}$ & \\
\hline Amanita vaginata f. alba (Bull.) Vesely & H. halimifolium & Taudiere et al. 2015 & \\
\hline Amphinema sp. & H. lasianthum & Santolamazza-Carbone et al. 2019 (ECM) & KY595998 \\
\hline \multirow[t]{3}{*}{ Astraeus hygrometricus (Pers.:Pers.) Morgan" } & $\begin{array}{l}\text { Halimium sp. } \\
\text { H. halimifolium }\end{array}$ & $\begin{array}{l}\text { Moreno-Arroyo } 2004 \\
\text { Moreau et al. 2007a }\end{array}$ & \\
\hline & H. halimifolium & This study & MT594495 \\
\hline & H. halimifolium & This study (ECM) & MT594496 \\
\hline \multirow[t]{3}{*}{ Boletus aereus Bull.:Fr." } & H. alyssoides & Martínez de Azagra Paredes et al. 1998 & \\
\hline & H. lasianthum & Oria-De-Rueda et al. 2008, 2009 & \\
\hline & $\begin{array}{l}\text { H. ocymoides, } \\
\text { H. viscosum }\end{array}$ & Martínez de Azagra Paredes et al. 1998 & \\
\hline \multirow[t]{3}{*}{ Boletus edulis Bull.:Fr." } & H. halimifolium & Moreau et al. $2007 \mathrm{a}$ & \\
\hline & H. lasianthum & Oria-De-Rueda et al. 2005, 2008, 2009 & \\
\hline & H. alyssoides & Dentinger et al. 2010 & EU231946 \\
\hline Boletus sp. & H. halimifolium & This study & MT594497 \\
\hline Cantharellus cfr. pallens Pilát & H. halimifolium & This study & \\
\hline Cantharellus subpruinosus Eyssart. \& Buyck ${ }^{\mathrm{d}}$ & H. halimifolium & Moreau et al. 2007a & \\
\hline Coltricia perennis (L.:Fr.) Murrill & H. halimifolium & Moreau et al. 2007a & \\
\hline \multirow[t]{2}{*}{ Coltricia cfr. perennis (L.:Fr.) Murrill } & H. halimifolium & This study & MT594498 \\
\hline & H. halimifolium & This study & MT594499 \\
\hline Cortinarius candelaris Fr. & H. halimifolium & This study & MT594500 \\
\hline $\begin{array}{l}\text { Cortinarius cedretorum var. halimiorum Brotzu \& } \\
\text { Peintner }\end{array}$ & H. halimifolium & Brotzu and Peintner 2009 & AY $900018^{\mathrm{e}}$ \\
\hline Cortinarius coeruleopallescens Contu* & H. halimifolium & This study & MT594501 \\
\hline \multirow[t]{2}{*}{ Cortinarius maculatocaespitosus Bidaud } & H. halimifolium & This study & MT594502 \\
\hline & H. halimifolium & This study & MT594503 \\
\hline $\begin{array}{l}\text { Cortinarius palazonianus Vila, A. Ortega \& } \\
\text { Fern.-Brime }\end{array}$ & H. halimifolium & Fernandez-Brime et al. 2014 & \\
\hline Cortinarius rigens (Pers.) Fr. & H. halimifolium & This study & MT594504 \\
\hline Cortinarius scobinaceus Malençon \& Bertault* & H. halimifolium & Moreau et al. $2007 \mathrm{a}^{\mathrm{f}}$, Moreau et a & \\
\hline
\end{tabular}


Table 1 (continued)

\begin{tabular}{l} 
Species \\
\hline Cortinarius variiformis Malençon $^{\#}$ \\
Descolea maculata Bougher ${ }^{\mathrm{g}}$ \\
Gyroporus pseudolacteus G. Moreno, \\
Carlavilla, Heykoop, Manjón \& Vizzini \\
Hebeloma cistophilum Maire*
\end{tabular}

Hebeloma cylindrosporum Romag." Hebeloma dunense L. Corb. \& R. Heim Hortiboletus rubellus (Krombh.) Simonini, Vizzini \& Gelardi Hygrophorus chrysodon (Batsch:Fr.) Fr." Hygrophorus cfr. eburneus (Bull.) Fr." Inocybe asterospora Quél.

Inocybe calida Velen. Inocybe corydalina Quél. Inocybe halophila R. Heim. Inocybe lacera (Fr.) P. Kumm. Inocybe pruinosa R. Heim" Inocybe tigrina Heim

Inocybe sp. 1

Inocybe sp. 2

Inocybe sp. 3

Laccaria bicolor (Maire) P.D. Orton ${ }^{\#}$

Laccaria proxima (Boud.) Pat.*

Laccaria sp.

Lactarius cistophilus Bon \& Trimbach*

Lactarius deliciosus (L.) Gray

Lactarius giennensis (Mor.-Arr. et al.) Pierotti ${ }^{\#}$

Lactarius hepaticus Plowr. ${ }^{1}$

Lactarius pseudoscrobiculatus Basso, Neville \& Poumarat

Lactarius subdulcis (Pers.) Gray?

Lactarius tesquorum Malençon*

Lactifluus brunneoviolascens (Bon) Verbeken

Lactifluus rugatus Kühn. \& Romagn. ${ }^{\#}$

Leccinellum corsicum (Rolland) Bresinsky \& Manfr. Binder*

Paxillus ammoniavirescens Contu \& Dessi ${ }^{\#}$ Pisolithus arrhizus (Scop.) Rauschert ${ }^{\#}$

Pisolithus sp. $1^{\mathrm{o}}$

\section{Host (Halimium)}

Reference

Sequence

H. halimifolium

H. halimifolium

H. lasianthum

H. halimifolium

H. halimifolium

H. halimifolium

H. lasianthum,

H. ocymoides

Halimium sp.

Halimium sp.

H. halimifolium

H. halimifolium

H. halimifolium

Halimium sp.

H. halimifolium

H. halimifolium

Halimium sp.

H. halimifolium

H. halimifolium

Halimium sp.

H. halimifolium

H. halimifolium

H. halimifolium

H. halimifolium

H. halimifolium

H. halimifolium

H. halimifolium

H. lasianthum

Halimium sp.

H. lasianthum

H. halimifolium

H. halimifolium

H. halimifolium

H. alyssoides, H. ocymoides

H. lasianthum,

H. ocymoides

H. halimifolium

H. halimifolium

H. halimifolium

H. halimifolium

H. lasianthum

H. halimifolium

$H$. halimifolium

H. halimifolium

H. halimifolium

H. halimifolium

H. halimifolium

H. halimifolium

$H$. halimifolium

H. halimifolium

Halimium sp.

H. halimifolium

H. halimifolium

This study

This study

Santolamazza-Carbone et al. 2019 (ECM)

This study

MT594505

MT594506

KY 654754

MT594507

Moreau et al. 2007a, Moreau et al. 2007b, Eberhardt et al. 2009

This study

Buscardo et al. 2012 (ECM)

MT594508

HQ625447

Moreno-Arroyo 2004

Moreno-Arroyo 2004

This study

MT594509

This study

This study

Moreno-Arroyo 2004

MT594510

MT594511

Moreno-Arroyo 2004 ${ }^{\mathrm{h}}$

Moreno-Arroyo 2004

Moreau et al. 2007a, Moreau et al. 2007b

Moreno-Arroyo 2004

Moreno-Arroyo 2004

This study

This study

This study

This study

This study

This study (ECM)

This study (ECM)

Santolamazza-Carbone et al. 2019 (ECM)

Moreno-Arroyo 2004

Santolamazza-Carbone et al. 2019 (ECM)

Leonardi et al. 2018

This study

de Carvalho 2016 (sECM),

Albuquerque-Martins et al. 2019 (sECM)

Vidal et al. 2019

Buscardo et al. 2012 (ECM)

HQ625465

This study

MT594520

This study (ECM)

This study (ECM)

MT594521

Moreau et al. 2007a

MT594522

Santolamazza-Carbone et al. 2019 (ECM)

KY681468

This study

MT594523

Leonardi et al. 2018

KU $885434^{\mathrm{m}}$

This study

This study

This study (ECM)

MT594524

Moreau et al. $2007 \mathrm{a}^{\mathrm{n}}$

This study

This study

This study

Moreno-Arroyo 2004

Moreau et al. 2007a

This study
MT594525

MT594526

MT594527

MT594528

MT594529 
Table 1 (continued)

\begin{tabular}{|c|c|c|c|}
\hline Species & Host (Halimium) & Reference & Sequence \\
\hline Pisolithus sp. 2 & H. halimifolium & This study (ECM) & MT594530 \\
\hline \multirow{2}{*}{ Rhizopogon luteolus Fr." } & Halimium sp. & Moreno-Arroyo 2004 & \\
\hline & H. ocymoides & Buscardo et al. 2012 (ECM) & HQ625448 \\
\hline Rhizopogon roseolus (Corda) Th. Fr. ${ }^{\#}$ & H. ocymoides & Buscardo et al. 2012 (ECM) & HQ625451 \\
\hline \multirow{5}{*}{$\begin{array}{l}\text { Russula ammophila (J.M. Vidal \& Calonge) } \\
\text { Trappe \& T.F. Elliott }\end{array}$} & Halimium sp. & Moreno-Arroyo $2004^{\mathrm{p}}$ & \\
\hline & Halimium sp. & Moreno-Arroyo et al. $2005^{\mathrm{p}}$ & \\
\hline & Halimium sp. & Vidal et al. $2002^{\mathrm{p}}$ & AJ438037 \\
\hline & Halimium sp. & Vidal et al. 2019 & MK105623 \\
\hline & H. halimifolium & Vidal et al. 2019 & \\
\hline Russula amoenicolor Romagn. & H. halimifolium & Moreau et al. $2007 \mathrm{a}$ & \\
\hline Russula cistoadelpha M.M. Moser \& Trimbach* & H. halimifolium & This study & \\
\hline Russula densifolia Secr. ex Gillet & H. lasianthum & Buscardo et al. 2012 (ECM) & HQ625470 \\
\hline Russula littoralis Romagn. & H. halimifolium & Moreau et al. $2007 \mathrm{a}$ & \\
\hline Russula monspeliensis Sarnari* & H. halimifolium & This study & MT594531 \\
\hline \multirow[t]{4}{*}{ Russula odorata Romagn." } & H. halimifolium & This study & MT594532 \\
\hline & H. halimifolium & This study & MT594533 \\
\hline & H. halimifolium & This study & MT594534 \\
\hline & H. halimifolium & This study (ECM) & MT594535 \\
\hline Russula praetervisa Sarnari $^{\#}$ & H. halimifolium & This study (ECM) & MT594536 \\
\hline Russula sardonia Fr. & H. ocymoides & Buscardo et al. $2012(\mathrm{ECM})^{\mathrm{q}}$ & HQ625452 \\
\hline Russula tyrrhenica Sarnari* & H. halimifolium & Moreau et al. $2007 \mathrm{a}$ & \\
\hline \multirow{2}{*}{$\begin{array}{l}\text { Russula vinaceodora (Calonge \& J.M. Vidal) } \\
\text { Trappe \& T.F. Elliot }\end{array}$} & Halimium sp. & Moreno-Arroyo et al. $2005^{\mathrm{r}}$ & \\
\hline & Halimium sp. & Vidal et al. $2002^{\mathrm{p}}$, Vidal et al. 2019 & AJ438034 \\
\hline Russula sp. & H. halimifolium & Carvalho et al. 2018 (ECM) & LT746014 \\
\hline Russula sp. 1 & H. halimifolium & This study (ECM) & MT594537 \\
\hline Scleroderma citrinum Pers. & H. lasianthum & Santolamazza-Carbone et al. 2019 (ECM) & KY694393 \\
\hline \multirow[t]{4}{*}{ Scleroderma meridionale Demoulin \& Malençon ${ }^{\#}$} & Halimium sp. & Moreno-Arroyo 2004 & \\
\hline & H. halimifolium & Leonardi et al. 2018 & MG264160 \\
\hline & H. halimifolium & Leonardi et al. 2018 (ECM) & MG367369 \\
\hline & H. halimifolium & This study & MT594538 \\
\hline Scleroderma polyrhizum (J.F. Gmel) Pers. & H. lasianthum & Santolamazza-Carbone et al. 2019 (ECM) & KY693661 \\
\hline Scleroderma sp. & H. halimifolium & This study & MT594539 \\
\hline \multirow[t]{2}{*}{ Serendipita vermifera (Oberw.) P. Roberts } & H. halimifolium & de Carvalho $2016(\mathrm{ECM})^{\mathrm{s}}$ & \\
\hline & H. halimifolium & Carvalho et al. $2018(\mathrm{ECM})^{\mathrm{s}}$ & LT746013 \\
\hline Thelephora cfr. caryophyllea (Schaeff.) Pers." & H. halimifolium & This study & \\
\hline \multirow[t]{5}{*}{ Thelephora terrestris Ehrh." } & H. halimifolium & Moreau et al. $2007 \mathrm{a}$ & \\
\hline & H. halimifolium & This study & MT594540 \\
\hline & H. halimifolium & This study (ECM) & MT594541 \\
\hline & H. lasianthum & Santolamazza-Carbone et al. 2019 (ECM) & KY693686 \\
\hline & $\begin{array}{l}\text { H. lasianthum, } \\
\text { H. ocymoides }\end{array}$ & Buscardo et al. 2012 (ECM) & HQ625443 \\
\hline Tomentella badia (Link) Stalpers & H. lasianthum & Santolamazza-Carbone et al. 2019 (ECM) & KY693714 \\
\hline $\begin{array}{l}\text { Tomentella terrestris (Berk. \& Broome) M.J. } \\
\text { Larsen }\end{array}$ & H. ocymoides & Buscardo et al. 2012 (ECM) & HQ625474 \\
\hline Tomentella sp. & H. halimifolium & Carvalho et al. 2018 (ECM) & LT746015 \\
\hline Tomentellopsis submollis (Svrček) Hjortstam & H. lasianthum & Santolamazza-Carbone et al. 2019 (ECM) & KY693726 \\
\hline Tomentellopsis sp. & H. ocymoides & Buscardo et al. 2012 (ECM) & HQ625483 \\
\hline Tricholoma equestre (L.:Fr.) P. Kumm. & $\begin{array}{l}\text { Halimium sp. } \\
\text { H. halimifolium }\end{array}$ & $\begin{array}{l}\text { Moreno-Arroyo } 2004 \\
\text { de Carvalho } 2016 \text { (sECM), Albuquerque-Martins et al. } \\
2019 \text { (sECM) }\end{array}$ & \\
\hline Tricholoma portentosum (Fr.) Quél & H. halimifolium & $\begin{array}{l}\text { de Carvalho } 2016 \text { (sECM), Albuquerque-Martins et al. } \\
2019 \text { (sECM) }\end{array}$ & \\
\hline $\begin{array}{l}\text { Tubariomyces hygrophoroides Esteve-Rav., } \\
\text { P.-A. Moreau \& C.E. Hermos }\end{array}$ & H. halimifolium & Alvarado et al. 2010 & \\
\hline $\begin{array}{l}\text { Tubariomyces inexpectata (M. Villarreal, } \\
\text { Esteve-Raventós, Heykoop \& E. Horak) } \\
\text { Esteve-Raventós \& Matheny }\end{array}$ & H. halimifolium & Moreau et al. $2007 \mathrm{a}^{\mathrm{u}}$ & \\
\hline \multirow{2}{*}{ Tylospora sp. } & H. halimifolium & de Carvalho 2016 (ECM) & $\mathrm{t}$ \\
\hline & & This study & MT594542 \\
\hline
\end{tabular}


Table 1 (continued)

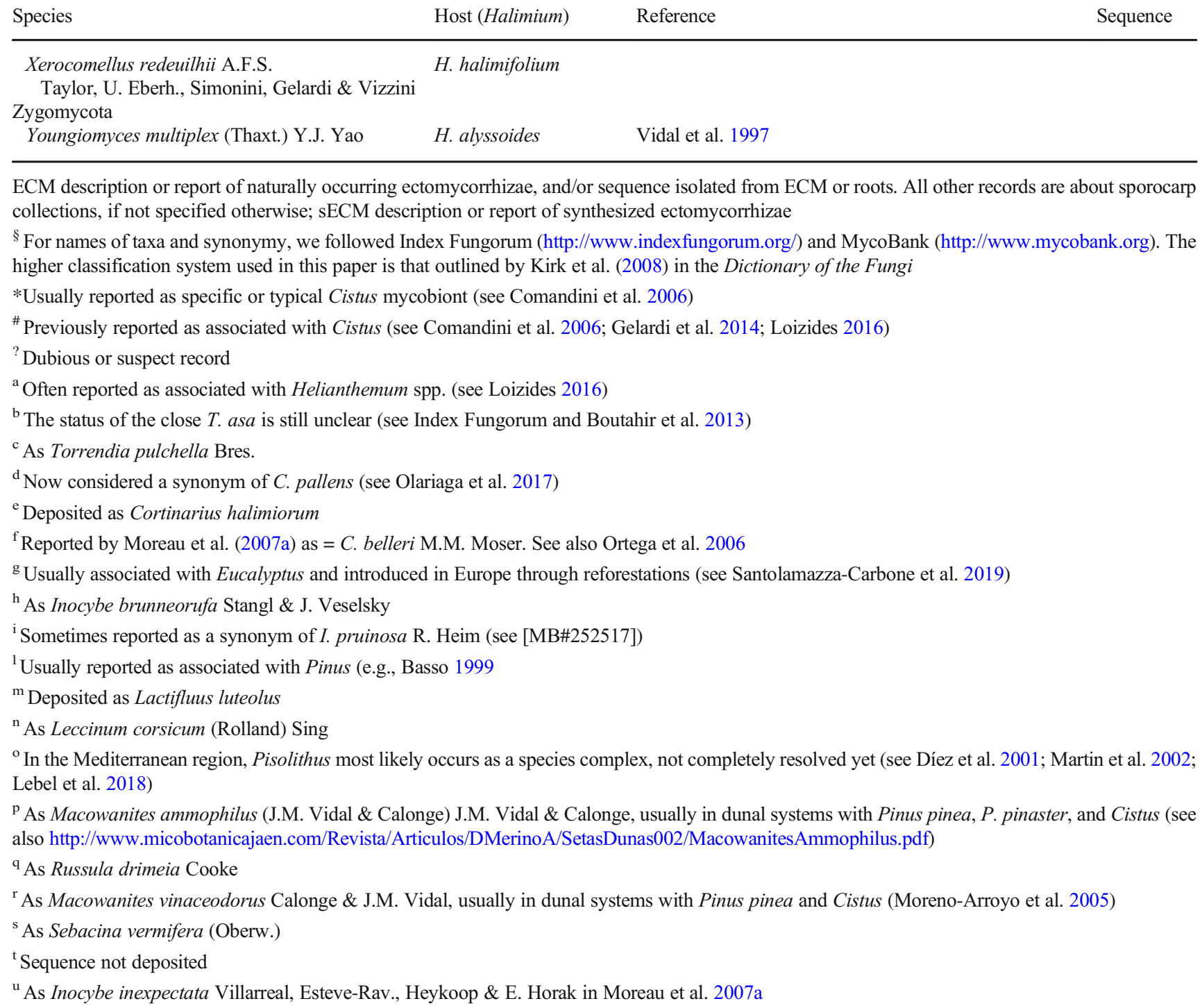

ECM description or report of naturally occurring ectomycorrhizae, and/or sequence isolated from ECM or roots. All other records are about sporocarp collections, if not specified otherwise; sECM description or report of synthesized ectomycorrhizae

${ }^{\S}$ For names of taxa and synonymy, we followed Index Fungorum (http://www.indexfungorum.org/) and MycoBank (http://www.mycobank.org). The higher classification system used in this paper is that outlined by Kirk et al. (2008) in the Dictionary of the Fungi

*Usually reported as specific or typical Cistus mycobiont (see Comandini et al. 2006)

\# Previously reported as associated with Cistus (see Comandini et al. 2006; Gelardi et al. 2014; Loizides 2016)

? Dubious or suspect record

${ }^{a}$ Often reported as associated with Helianthemum spp. (see Loizides 2016)

${ }^{\mathrm{b}}$ The status of the close T. asa is still unclear (see Index Fungorum and Boutahir et al. 2013)

${ }^{\mathrm{c}}$ As Torrendia pulchella Bres.

${ }^{\mathrm{d}}$ Now considered a synonym of C. pallens (see Olariaga et al. 2017)

${ }^{\mathrm{e}}$ Deposited as Cortinarius halimiorum

${ }^{\mathrm{f}}$ Reported by Moreau et al. (2007a) as $=$ C. belleri M.M. Moser. See also Ortega et al. 2006

${ }^{\mathrm{g}}$ Usually associated with Eucalyptus and introduced in Europe through reforestations (see Santolamazza-Carbone et al. 2019)

${ }^{\mathrm{h}}$ As Inocybe brunneorufa Stangl \& J. Veselsky

${ }^{\mathrm{i}}$ Sometimes reported as a synonym of I. pruinosa R. Heim (see [MB\#252517])

${ }^{1}$ Usually reported as associated with Pinus (e.g., Basso 1999

${ }^{\mathrm{m}}$ Deposited as Lactifluus luteolus

${ }^{\mathrm{n}}$ As Leccinum corsicum (Rolland) Sing

${ }^{\circ}$ In the Mediterranean region, Pisolithus most likely occurs as a species complex, not completely resolved yet (see Díez et al. 2001; Martin et al. 2002; Lebel et al. 2018)

${ }^{\mathrm{p}}$ As Macowanites ammophilus (J.M. Vidal \& Calonge) J.M. Vidal \& Calonge, usually in dunal systems with Pinus pinea, P. pinaster, and Cistus (see also http://www.micobotanicajaen.com/Revista/Articulos/DMerinoA/SetasDunas002/MacowanitesAmmophilus.pdf)

${ }^{\mathrm{q}}$ As Russula drimeia Cooke

${ }^{\mathrm{r}}$ As Macowanites vinaceodorus Calonge \& J.M. Vidal, usually in dunal systems with Pinus pinea and Cistus (Moreno-Arroyo et al. 2005)

${ }^{\mathrm{s}}$ As Sebacina vermifera (Oberw.)

${ }^{\mathrm{t}}$ Sequence not deposited

${ }^{\mathrm{u}}$ As Inocybe inexpectata Villarreal, Esteve-Rav., Heykoop \& E. Horak in Moreau et al. 2007a

based on reports of field observations of sporocarps associations with potential hosts. The dataset contains both personal collections and observations and information collated from a variety of published and web-based sources. Literature databases available to authors (e.g., Agricola, Scopus, PubMed, ISI Web of Science, ResearchGate) were searched for articles on Halimium and associated mycobionts. Sequences of Halimium ECM fungi were retrieved from either GenBank or UNITE. Fungal taxa belonging to genera for which the mycorrhizal status is currently uncertain were not listed (for a comprehensive list of ectomycorrhizal fungal genera and the criteria used to ascertain mycorrhizal status, see Rinaldi et al. 2008 and Comandini et al. 2012). Only records clearly mentioning (potential) Halimium hosts were included in the data matrix (this includes records from mixed Cistus/Halimium stands). Evidence from studies on the morpho-anatomical and/or molecular characterization of ectomycorrhizae formed by fungal species on Halimium spp. were also inserted in the data set, excluding uncultured fungus sequences and fungal species not identified at least at genus level. In addition to studies concerning naturally occurring, field-collected mycorrhizae, data coming from synthesized mycorrhizae were also considered, although it must be stressed that associations induced in laboratory experiments may not occur under field conditions. Despite all efforts to cover as many bibliographic sources as possible, our literature survey might clearly be partial and incomplete. Reports of putative mycorrhizal relationships based solely on sporocarps associations rather than confirmed by direct inspection of ectomycorrhizae are obviously subject to an unquantifiable degree of error, especially when 
more than one potential plant hosts are present (e.g., mixed Halimium stands with Cistus, Pinus, and/or Quercus). Finally, the identification of some fungi in the references that we have considered may not be correct.

\section{Results}

\section{The Halimium ectomycorrhizal guild}

Our effort to gauge the diversity of ectomycorrhizal fungi linked to Halimium, through both direct field sampling and the compendium of literature records, resulted in 154 listed entries, corresponding to 102 species belonging to 35 genera from Ascomycota, Basidiomycota, and Zygomycota (Table 1). This tally excludes a few cases of possible synonymy, e.g., Inocybe halophila R. Heim = I. pruinosa R. Heim and Cantharellus cfr. pallens $=$ C. subpruinosus Eyssart. \& Buyck, and the dubious record of Lactarius subdulcis (Pers.) Gray, a known Fagus symbiont whose sequence was probably misbranded and it is likely to be L. hepaticus Plowr. Fiftyseven of the listed records, which refer to 41 different species, were provided by our field work in Halimium plots in southwestern Sardinia, Italy; of these, 29 species are reported here for the first time as linked to Halimium. Most of the ecologically key ectomycorrhizal fungal genera are represented in the list, with Russula (13 species), Amanita (12 spp.), Inocybe (10 spp.), Lactarius/Lactifluus (9 spp., including the synthesized ECMs of L. deliciosus (L.) Gray, see below), and Cortinarius (8 spp.), accounting for more than half of all species. As in other genera of Cistaceae (e.g., Cistus and Helianthemum), it is apparent from the entries in the list that hypogeous ascomycetes make a significant part of the Halimium ectomycorrhizal contingent (Table 1). Several Terfezia species, including the newly described $T$. dunensis Ant. Rodr., Cabero, Luque \& Morte (Crous et al. 2019), were reported as associated with Halimium. In our plots, we isolated the ECMs formed by Tuber oligospermum Tul. \& C. Tul. (Trappe) on $H$. halimifolium (see Fig. 3e), molecularly confirming the identity of host plant (data not shown). Belonging to the Puberulum group, or the so-called whitish truffles, T. oligospermum has been reported previously as a Quercus and Cistus mycobiont (Comandini et al. 2006; Lancellotti et al. 2016), and it is the first Tuber species ever to be proven to form ECMs with Halimium.

While the vast majority of records of Halimium-linked ectomycorrhizal fungi derives from aboveground observations of sporocarps, a fairly good number of collections and molecular characterizations of ECM tips have permitted to open a window on the belowground reality. In particular, the works conducted by Buscardo et al. (2012), de Carvalho (2016), and Carvalho et al. (2018) in Pinus-dominated forests with understorey shrubs in Portugal, and by Santolamazza-
Carbone et al. (2019) in mixed shrublands in northwestern Spain, have resulted in the molecular identification of an array of ectomycorrhizal fungi in the Halimium spp. roots. These included Cenococcum geophilum Fr., Terfezia spp., Amanita citrina (Schaeff.:Fr.) Pers., Amphinema sp., Descolea maculata Bougher, Hebeloma cistophilum Maire, Laccaria spp., Lactarius hepaticus, Rhizopogon spp., Russula spp., Scleroderma spp., Serendipita vermifera (Oberw.) P. Roberts, Thelephora terrestris Ehrh., Tomentella spp., Tomentellopsis spp., and Tylospora sp. (Table 1). In addition, Albuquerque-Martins et al. (2019) described the synthesized ECMs of H. halimifolium with Tricholoma equestre (L.:Fr.) P. Kumm., T. portentosum (Fr.) Quél, and Lactarius deliciosus. However, it is well-known that successful pure-culture synthesis of ectomycorrhizae not necessarily reflects naturally occurring partnerships between given host plant-mycobiont pairs (although Halimium-linked T. equestre has been collected also in the field). During our study, through random sampling of soil in the proximity of $H$. halimifolium shrubs, we isolated eleven distinct morphotypes (Table 1; Fig. 3). In six cases (Astraeus hygrometricus (Pers.) Morgan, Lactarius hepaticus, Lactifluus rugatus Kühn. \& Romagn., Russula odorata Romagn., Scleroderma meridionale, and Thelephora terrestris), sporocarps of the same species were also collected. Five other species (Tuber oligospermum, Inocybe sp. 3, Pisolithus sp. 2, Russula praetervisa Sarnari, and Russula sp.) were collected only belowground. The full morphological characterization of selected morphotypes is under way, and will be presented in a complimentary work.

\section{Walking hand in hand with Halimium}

Some of the mycorrhizal fungi we found associated with Halimium deserve a special mention and further notes. One of the most common ectomycorrhizal fungal species present in our H. halimifolium plots was Scleroderma meridionale (MycoBank MB\#323250). Basidiomata of this species are large, globose, characterized by a smooth-to-finely furfuraceous peridium of an intense sulfur yellow color, which becomes brighter in the long pseudostipe, usually immersed deep in the soil (Fig. 4a). The habit is solitary, occasionally gregarious, found mostly in sandy soils and dunes. Originally described on the basis of collections from southern Portugal, continental France, Corsica, and Morocco, it occurs in all the Mediterranean basin, including Greece, Macedonia, and Turkey (Rusevska et al. 2014; Dimou et al. 2016). It is also reported from North America, from Florida to Arizona, and Oregon (Guzmán and Ovrebo 2000; Kuo 2004, http://www. svims.ca/council/Sclero.htm). However, the identity of these collections still awaits confirmation: indeed, preliminary molecular data seem to indicate that the North American " $S$. meridionale" belongs to a distinct, so far undescribed, taxon (D. Puddu, M. Leonardi, A.C. Rinaldi, unpublished data). 
Based on field observations, S. meridionale has been reported as associated with both evergreen and deciduous species of Quercus, Pinus, and also Cistus (Comandini et al. 2006; Phosri et al. 2009; Dimou et al. 2016). We recently described the morpho-anatomical features of the ectomycorrhizae formed by $S$. meridionale on $H$. halimifolium, with the help of confocal laser scanning microscopy; the mycobiont and host plant identity from the ECM root tips were verified through molecular tools (Leonardi et al. 2018). This was the first description of an ectomycorrhiza on Halimium. The features of this ECM - felty mantle surface, whitish with silver patches, mantle surface characterized by a network of branched hyphae organized in hyphal bundles, small dimension of mycorrhizal system - are similar to those reported for the few described naturally occurring Scleroderma ECMs and to other ECMs formed by Cistaceae (Leonardi et al. 2018).

Another interesting species recorded in our collection site was Alessioporus ichnusanus (MB\#808530). The taxon corresponds to a boletoid species recently segregated from Xerocomus Quél. to typify the new genus Alessioporus Gelardi, Vizzini \& Simonini which currently accommodates two species. Its type and epitype were collected in Sardinia in 1980 (Galli 1981) and in 2003 (Gelardi et al. 2014), respectively, in Quercus spp. and Cistus spp. forests, in the province of Medio Campidano, $60 \mathrm{~km}$ from our Halimium plots. In addition to the type collections, the taxon has been recorded in different localities in Sardinia, as well as in Sicily, continental Italy (Brotzu 1988; Alessio 1991; Brotzu and Colomo 2009; Gelardi 2010; Illice et al. 2011) and other Mediterranean countries, as France (Eyssartier and Roux 2011), Greece (Polemis et al. 2012), and Spain (Muñoz 2005). Alessioporus ichnusanus can be recognized by the ochraceous-brown, dark olive-brown-to-copper-brown pileus with brownish-black fibrils (Fig. 4b). But one of the most important morphological character that define this species is a narrow pseudo-annulus in the middle part of the stipe formed by the remnants of the connection between the pileus margin and the stipe cortex during the primordial stage (Galli 2013). Currently, Alessioporus ichnusanus is considered an uncommon or rare species that has recently been included in the Red List of Italian macrofungi as an endangered species (Rossi et al. 2013) and in the IUCN red list as vulnerable (Persiani 2019; Angelini et al. 2020).

Keeping with the Boletales, Gyroporus pseudolacteus G. Moreno, Carlavilla, Heykoop, Manjón \& Vizzini (MycoBank MB\#356882) is an interesting finding. This species has been recently described from a material collected in Spain, on sandy soil under Pinus pinaster (Crous et al. 2016). To the best of our knowledge, this is the first confirmed record of this species not only for Sardinia but also for Italy. Gyroporus pseudolacteus can be distinguished from the common and closely related Gyroporus cyanescens (Bull.) Quél. by its larger habit, the longer stipe in relation to the pileus diameter, and the "deep and persistently indigo blue when handled or bruised" (Crous et al. 2016) (Fig. 4c). According to Vizzini and co-workers, G. cyanescens should be considered a complex of cryptic species (Vizzini et al. 2015) which is being unraveled with the help of molecular tools (see Crous et al. 2017), even though some of these taxa are still being treated as synonyms by some fungal names databases. While this is the first mention of Halimium as the probable host, the putative association of Gyroporus with cistaceous plants is not unprecedented. Although the six (not universally accepted) known European species of Gyroporus-G. ammophilus (M.L. Castro \& L. Freire) M.L. Castro \& L. Freire; G. castaneus (Bull.) Quél.; G. cyanescens; G. lacteus Quél.; G. pseudocyanescens G. Moreno, Carlavilla, Heykoop, Manjón \& Vizzini; and G. pseudolacteus - are usually reported from under coniferous (Pinus) or decidous (Castanea, Fagus, Quercus) hosts (Vizzini et al. 2015; Crous et al. 2016, 2017), G. ammophilus was found along the Atlantic coast of the Iberian Peninsula "on fixed dunes in association with Pinus spp., or, less frequently with other trees and shrubs, such as Quercus suber L. and Cistus salviaefolius (sic!), on sandy soils" (Castro and Freire 1995).

Lactarius hepaticus (MycoBank MB\#224000) was, by far, the most common milkcap in our Halimium stands (Fig. 4d). This was an unexpected finding, since this species belonging to the subgenus Russularia is commonly associated with Pinus and, more occasionally, other conifers such as Picea and Pseudotsuga (Heilmann-Clausen et al. 1998; Basso 1999). Uncommon to rare/absent in northern Europe is more frequent in Britain, the Netherlands, and, above all, in the Mediterranean area. This species is characterized by its convex to applanate with a depressed center cap, with liver-brown color (hence the epithet); the milk is white, turning yellow on a tissue (Pierotti 2005). Intriguingly, in central Portugal, L. hepaticus was part of shared ECM networks between understory shrubs and pine trees in a Pinus-dominated forest, being detected with molecular tools on the roots of both Pinus pinaster and Halimium lasianthum and H. ocymoides (Lam.) Willk. (Buscardo et al. 2012). Along the coastal area in Sardinia, where our Halimium plots are situated, Pinus stands are also frequent, originated from extensive reforestation plans carried out during the last century. We collected L. hepaticus in these stands as well, where $H$. halimifolium is frequent both in the understory and at the edges of the pine forest. Lactarius hepaticus was abundant as sporocarps among Halimium shrubs and on their roots in proximity of Pinus, confirming the existence of shared ECM networks, but it occurred also in pure Halimium plots distant several kilometers from pine trees stands, in areas where Pinus, at the best of our knowledge, has never been present. This suggests colonization of new ECM plant hosts (like Halimium) by L. hepaticus by means other than root networking, such as spore dispersal. More work is underway to investigate $L$. hepaticus ecological plasticity. 
Fig. 3 Habit of some of the ectomycorrhizal morphotypes collected under Halimium halimifolium during this study. a Astraeus hygrometricus. b Lactarius hepaticus. c Russula monspeliensis. d Russula praetervisa. e Tuber oligospermum
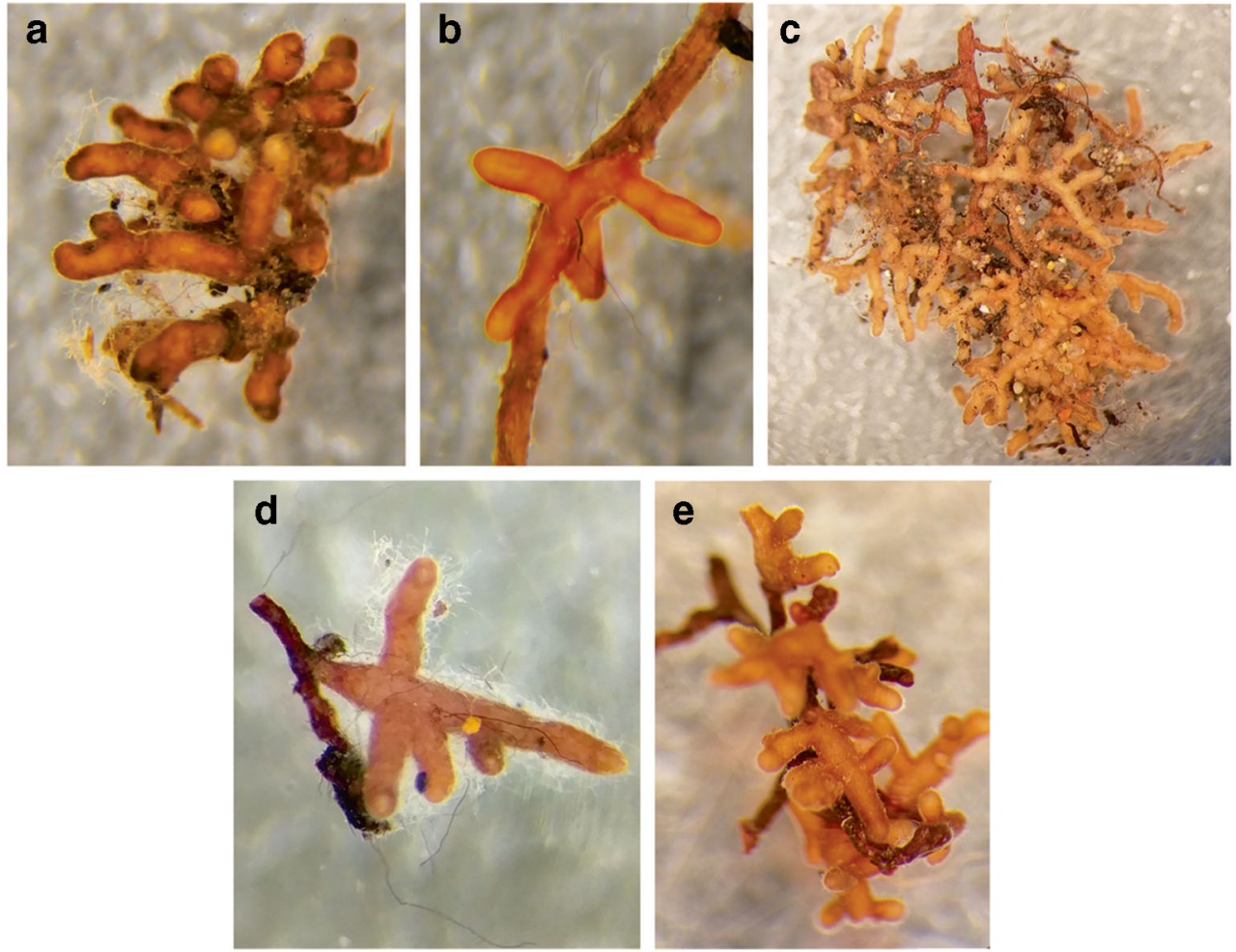

Lactifluus brunneoviolascens (Bon) Verbeken (MycoBank MB\#564601) is another uncommon species, reported here for the second time in Sardinia (see Lalli and Pacioni 1992). It was previously named $L$. luteolus Peck, which is now known to be the correct name for a North American species (Verbeken et al. 2012; De Crop et al. 2017). Both species belong to the newly erected section Phlebonemi (R. Heim ex Verbeken) Verbeken (= Lactarius subsect. Luteoli Pacioni \& Lalli) (Verbeken et al. 2012). Lactifluus brunneoviolascens is easily distinguished in the field by the whitish/whitish-cream color of the pileus, with velvety cuticle, dry even in very humid weather, finely crenulated at the edge, stained ocherbrown with age; the context is firm, whitish then darker ocherbrownish, with a sweet taste and an unpleasant fishy smell; the latex is fluid, abundant, opalescent white, immutable if isolated on glass, slowly but strongly browning in contact with the lamellae or on absorbent paper (Fig. 4e). We studied two different collections of this Lactifluus from almost pure $H$. halimifolium stands. Another collection was recently recorded from southeastern Sardinia, under Quercus (Alberto Mua, personal communication), a more usual habitat (sometimes it also occurs in mixed Quercus-Pinus forests) for this species with a prevalently Mediterranean distribution that prefers dry and sandy soils (Basso 1999; Pierotti 2002).

Among the various Cortinarius species encountered during this study and likely linked to Halimium, Cortinarius coeruleopallescens Contu (MycoBank MB\#459976) deserves a mention (Fig. 4f). This taxon, not uncommon in our plots, was described in 1999, when Marco Contu raised to species level a fungus he encountered in Sardinia, and that had been observed by other researchers 2 years earlier in Spain and originally thought to be a variety of $C$. croceocoeruleus (Pers.) Fr., C. croceocoeruleus var. meridionalis Bidaud, A. Ortega \& Mahiques (Ortega et al. 1997; Contu 1999). The collections from both Spain and Sardinia were associated with Cistus, while C. croceocoeruleus is typical of central European coniferous and broadleaved forests. Another species linked to Halimium and worthy of remark is Cortinarius cedretorum var. halimiorum Brotzu \& Peintner (Mycobank MB\#580057) (Table 1). This beautiful variety in the subgenus Phlegmacium was described (originally reported in a field guide as C. halimiorum; see Brotzu and Colomo 2009) on the basis of material collected on a dune system in the northeastern part of Sardinia (Brotzu and Peintner 2009). Despite the fact that the vegetation system in this case is more complex than the one present in our $H$. halimifolium stands, with psammophile coastal associations where H. halimifolium is present together with other floristic entities, such as Cistus spp., Pistacia lentiscus L., Juniperus phoenicea L., and Arbutus unedo L. (see Arrigoni 1996), the link between this specific Cortinarius and Halimium was apparent to the researchers (Brotzu and Peintner 2009). 

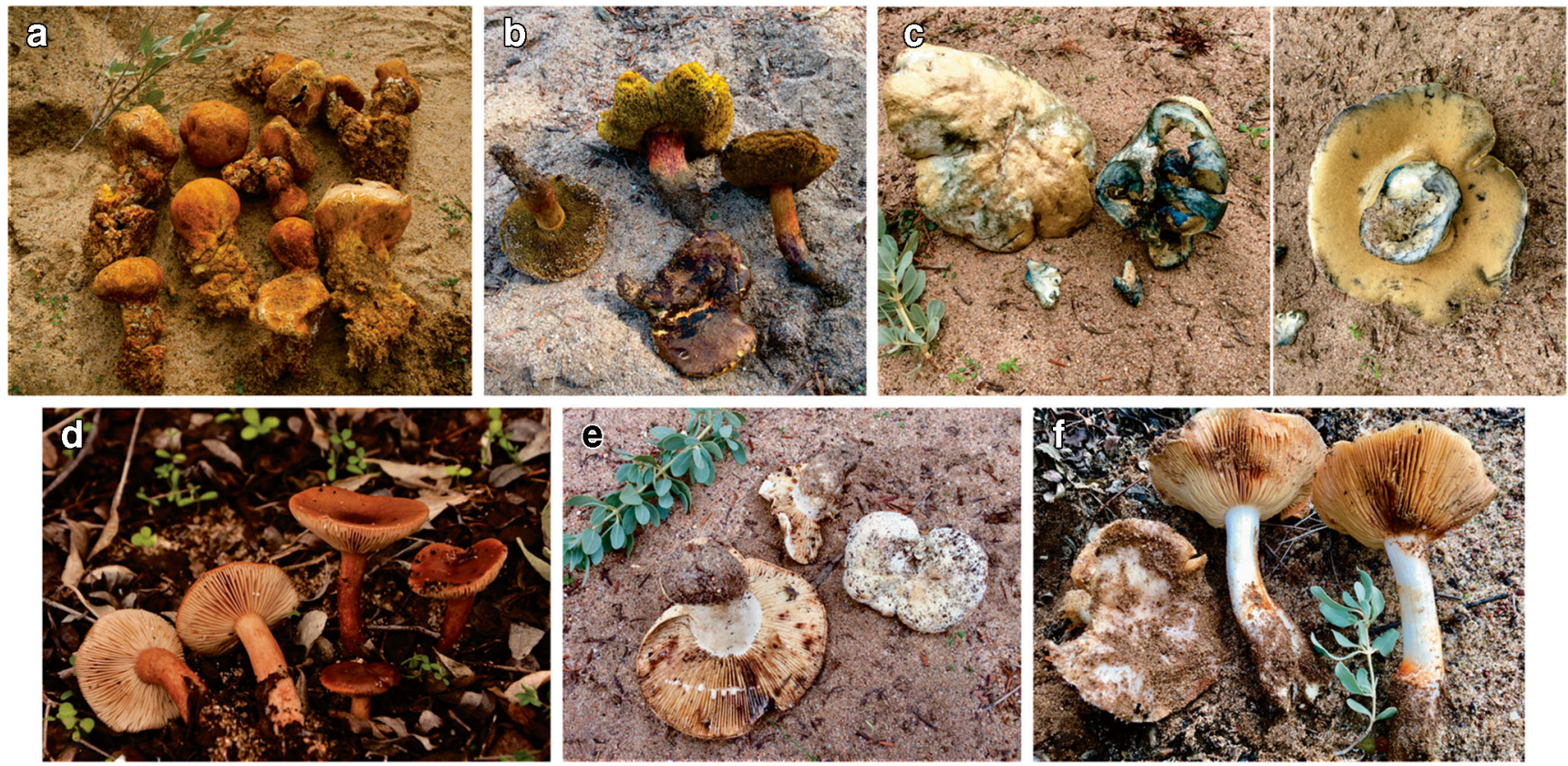

Fig. 4 Sporocarps of selected species discussed in the text. a Scleroderma meridionale. b Alessioporus ichnusanus. c Gyroporus pseudolacteus. d Lactarius hepaticus. e Lactifluus brunneoviolascens. f Cortinarius coeruleopallescens

\section{Discussion}

Using the dataset assembled in Table 1, it is not straightforward to compare the above- and belowground composition of Halimium-linked ECM fungal communities. It should be remarked, indeed, that the dataset contains records from studies conducted with different goals and methodologies. For example, with the exception of the present work, studies providing ECM records did not consider sporocarps at all (Buscardo et al. 2012; de Carvalho 2016; Carvalho et al. 2018; Santolamazza-Carbone et al. 2019). Conversely, many sporocarp observations are derived from surveys that disregarded belowground views. It is technically easier to collect and identify sporocarps than ECMs, and belowground diversity tends to be undersampled. To get a clearer picture of soil and root fungal communities in Halimium scrublands, we started an ongoing metabarcoding project in our Sardinian Halimium stands. Preliminary results show the presence on Halimium roots of additional ECM genera, such as Geopora, Helvella, and Wilcoxina, and species, like Astraeus telleriae M.P. Martín, Phosri \& Watling (Geml et al., unpublished data). This study, when complete, will render a more complete view of the composition of belowground ECM community and its correlation with aboveground diversity.

So far, no Halimium-specific or preferential ECM mycobiont has emerged, with the possible exception of Cortinarius cedretorum var. halimiorum Brotzu \& Peintner. However, since our knowledge of this host plant and its ECM guild is rudimental, this ecological liaison will most likely be recognized in the near future, possibly accompanied by the description of new fungal species. Our failure to identify a perfect molecular match for several of the sequences obtained during this study supports this speculation. Nearly $40 \%$ of the species listed in Table 1 (41, counting Terfezia spp.) have been previously reported as Cistus-associated (see Comandini et al. 2006; Loizides 2016). This includes wellknown "Cistus-specific" mycobionts, such as Amanita cistetorum Contu \& Pacioni, Hebeloma cistophilum, Lactarius cistophilus Bon \& Trimbach, Lactarius tesquorum Malençon (see Nuytinck et al. 2004; Comandini and Rinaldi 2008), and Leccinellum corsicum (Rolland) Bresinsky \& Manfr. Binder. Given the Halimium-Cistus phylogenetic affinity, and the co-occurrence of the two host plants in many ecological settings, the extensive ECM sharing is not particularly surprising, at least when the concept of host-specificity is applied at the plant family level (Cistaceae). Another cluster of Halimium mycobionts are also linked to Quercus, on the basis of a number of field observations (Leonardi et al. 2016; Comandini et al. 2018). This group includes Alessioporus ichnusanus (Alessio, Galli \& Littini) Gelardi, Vizzini \& Simonini (also known to be associated to a lesser extent, with Cistus spp.); Hortiboletus rubellus (Krombh.) Simonini, Vizzini \& Gelardi; Xerocomellus redeuilhii A.F.S. Taylor, U. Eberh., Simonini, Gelardi \& Vizzini; Lactifluus rugatus; and Scleroderma meridionale. Finally, a bunch of Halimium symbionts are shared with Pinus, as demonstrated in studies carried out in Portugal (Buscardo et al. 2012; de Carvalho 2016; Carvalho et al. 2018). Again, "host-specific" Pinus mycobionts, such as Rhizopogon spp., Russula sardonia Fr. (= Russula drimeia Cooke), and Lactarius hepaticus, were detected on both Halimium and Pinus roots, together with 
more generalist fungal species like Serendipita vermifera (Oberw.) P. Roberts, Thelephora terrestris, and Tomentella terrestris (Berk. \& Broome) M.J. Larsen. In the study in central Portugal by Buscardo and colleagues, it is showed that about $30 \%$ of the identified ECM fungal species were common to pine and Halimium spp., with shared ECM fungal species representing up to $80 \%$ of the total fungal abundance in some stands (Buscardo et al. 2012). To expand even further the plasticity of Halimium as ECM host plant, H. lasianthum was shown to establish symbiotic interactions with the Australian Descolea maculata Bougher in Spain, spreading from nearby Eucalyptus plantations (Santolamazza-Carbone et al. 2019). In Corsica, H. halimifolium was reported to have a contingent of $12 \mathrm{ECM}$ fungal species, shared in different proportions with Cistus, Quercus, and Pinus, but also with other host plants like Castanea, Fagus, Corylus, Populus, Salix, Alnus, Betula, and Abies (Taudiere et al. 2015).

The ability of Cistaceae to develop common mycelial networks by sharing ECM fungal partners with neighboring plants is a crucial ecological trait that has not been appropriately appreciated. As stressed by Randy Molina and Thomas Horton, "common mycelial networks (CMNs) of mycorrhizal fungi connecting neighboring host plants affect ecosystem processes and community dynamics including seedling establishment, plant succession, and ecosystem resiliency" (Molina and Horton 2015). Based on our current knowledge of Halimium and Cistus ECM communities, it is apparent that these are largely shaped by "ecological specificity" rather than host-specificity. Despite the fact that both genera have host preferential (or even exclusive) fungal partners, large part of their mycorrhizal associations seems rather driven by environmental (soil composition, for example) and biological factors, like the presence of other host plants in the same or neighboring areas, thus going beyond host-fungus genetic compatibility due to co-evolution. Either in pure shrublands, as in our Sardinian stands, or at the edges or in the understory of Quercus and Pinus forests, especially when growing on poor and/or degraded soils, Halimium might thus play a key ecological role, maintaining ECM fungal diversity, favoring vegetation succession and dynamics, and assisting ecosystem resilience following disturbance, thanks to common mycelial networks and possibly spore dispersal of ECM mycobionts. A similar function has been recognized for Cistus. In Spain, many of the fungal species associated with Cistus ladanifer $\mathrm{L}$. were found to be shared with Pinus pinaster Aiton, suggesting a role in the regeneration of Pinus stands after wildfire (Martín-Pinto et al. 2006). In this context, it is relevant to note that Cistus and possibly Halimium are dual-mycorrhizal plants, capable of hosting both arbuscular mycorrhizal and ectomycorrhizal associations. Several early successional ECM hosts like Alnus, Populus, and Salix share this feature. In the Mediterranean ecosystem, Cistaceae definitely play a major role in secondary succession following major disturbances like fire (or even human activity). Benefits deriving from dual-mycorrhizal colonization thus extend from interested plants - endowed with greater survival, growth, and nutrient uptake - to ecosystems, favoring establishment and improving survival on adverse sites of connected ECM plants (Teste et al. 2020).

\section{Conclusions}

We are just starting to unveil the complexity of Halimium mycorrhizal biology and ecology, especially for what concerns host-specificity of associated mycobionts and patterns of shared mycorrhizal networks with neighboring host plants. The general poor knowledge of Halimium as an ectomycorrhizal host has led to relatively few records of potentially associated fungal species based on observations of sporocarp occurrence. Hopefully, this and other works will increase the awareness of researchers, providing us in the near future with fresh data coming from fungal forays. Also, wellplanned molecular studies examining mycorrhizal specificity at the root tip scale are bound to disclose many details of the structure and dynamics of Halimium-linked ectomycorrhizal communities in multiple ecological settings.

Funding Open access funding provided by Università degli Studi di Cagliari within the CRUI-CARE Agreement. ANMF was supported by Coordenação de Aperfeiçoamento Pessoal de Nivel Superior-BrazilFinance Code 001 (CAPES-DS and PDSE fellowship grants).

Data availability All associated data are deposited in public repositories.

\section{Compliance with ethical standards}

Conflict of interest The author declares that they have no conflict of interest.

Ethics approval not applicable.

Consent to participate not applicable.

Consent for publication not applicable.

Code availability not applicable

Open Access This article is licensed under a Creative Commons Attribution 4.0 International License, which permits use, sharing, adaptation, distribution and reproduction in any medium or format, as long as you give appropriate credit to the original author(s) and the source, provide a link to the Creative Commons licence, and indicate if changes were made. The images or other third party material in this article are included in the article's Creative Commons licence, unless indicated otherwise in a credit line to the material. If material is not included in the article's Creative Commons licence and your intended use is not permitted by statutory regulation or exceeds the permitted use, you will need to obtain permission directly from the copyright holder. To view a copy of this licence, visit http://creativecommons.org/licenses/by/4.0/. 


\section{References}

Agerer R (1991) Characterization of ectomycorrhiza. In: Norris JR, Read DJ, Varma AK (eds) Methods in microbiology, vol. 23. Techniques for the Study of Mycorrhiza. San Diego, Academic Press. Pp. 25-73

Albuquerque-Martins R, Carvalho P, Miranda D, Gonçalves MT, Portugal A (2019) Edible ectomycorrhizal fungi and Cistaceae. A study on compatibility and fungal ecological strategies. PLoS One 14:e0226849

Alessio CL (1991) Boletus Dill. ex L. (supplemento). Fungi Europaei 2a. Saronno, Italy: Libreria Editrice Biella Giovanna

Alvarado P, Manjón JL, Matheny PB, Esteve-Raventós F (2010) Tubariomyces, a new genus of Inocybaceae from the Mediterranean region. Mycologia 102:1389-1397

Angelini P, Antonini D, Antonini M, et al. (2020) New insights on the occurrence and conservation status in Italy of Alessioporus ichnusanus (Boletaceae), an IUCN red listed mycorrhizal species. Plant Biosyst. https://doi.org/10.1080/11263504.2020.1813832

Arrigoni PV (1996) La vegetazione del complesso dunale di Capo Comino (Sardegna nord-orientale). Parlatorea 1:35-45

Basso MT (1999) Lactarius Pers. Fungi Europaei 7. Alassio, Italy: Mykoflora

Beddiar A, Adouane M, Boudiaf I, Fraga A (2015) Mycorrhizal status of main spontaneous or introduced forest trees in El Tarf province (Algerian north-east). Online J Sci Technol 5:40-45

Boutahir S, Iotti M, Piattoni F, Zambonelli A (2013) Morphological and molecular characterization of Tuber oligospermum mycorrhizas. Afr J Agric Res 8:4081-4087

Brotzu R (1988) Guida ai funghi della Sardegna, 1a edn. Editrice Archivio Fotografico Sardo, Nuoro

Brotzu R, Colomo S (2009) I funghi della Sardegna, vol 1-9. Editrice Archivio Fotografico Sardo, Nuoro

Brotzu R, Peintner U (2009) Cortinarius cedretorum var. halimiorum, a new variety of a Phlegmacium associated with Halimium halimifolium (Cistaceae) in Mediterranean costal sand dunes. Bresadoliana 1:25-44

Buscardo E, Rodríguez-Echeverría S, Barrico L, García MÁ, Freitas H, Martín MP, De Angelis P, Muller LAH (2012) Is the potential for the formation of common mycorrhizal networks influenced by fire frequency? Soil Biol Biochem 46:136-144

Camprubi A, Estaun V, Calvet C (2011) Greenhouse inoculation of psammophilic plant species with arbuscular mycorrhizal fungi to improve survival and early growth. Eur J Soil Biol 47:194-197

Carvalho P, Martins R, Portugal A, Gonçalves MT (2018) Do mycorrhizal fungi create below-ground links between native plants and Acacia longifolia? A case study in a coastal maritime pine forest in Portugal. Web Ecology 18:105-114

Castro ML, Freire L (1995) Gyroporus ammophilus, a new poisonous bolete from the Iberian Peninsula. Persoonia 16:123-126

Chatin A (1891) Contribution a l'histoire botanique de la truffe. Deuxiéme note: Terfâs ou truffes d'Afrique (et d'Arabie), genres Terfezia et Tirmania. Comptes Rendus de l'Académie des sciences, sér. 3. Sci Vie 112:136-141

Chevalier G (2014) The European desert truffles. In: Kagan-Zur V, RothBejerano N, Sitrit Y, Morte A (eds) Desert truffles. Soil Biology, vol 38. Berlin-Heidelberg: Springer. Pp. 121-141

Civeyrel L, Leclercq J, Demoly J-P, Agnan Y, Quèbre N, Pélissier C, Otto T (2011) Molecular systematics, character evolution, and pollen morphology of Cistus and Halimium (Cistaceae). Plant Syst Evol 295:23-54

Comandini O, Rinaldi AC (2008) Lactarius cistophilus Bon \& Trimbach + Cistus sp. Descriptions Ectomycorrhizae 11/12:83-88

Comandini O, Contu M, Rinaldi AC (2006) An overview of Cistus ectomycorrhizal fungi. Mycorrhiza 16:381-395
Comandini O, Rinaldi AC, Kuyper TW (2012) Measuring and estimating ectomycorrhizal fungal diversity: a continuous challenge. In: Pagano M (ed) In: Mycorrhiza: occurrence in natural and restored environments. Nova Science Publishers, New York, pp 165-200

Comandini O, Paulis S, Rinaldi AC (2018) Sardinia: mycovisions from a charming land. Curr Res Environ Appl Mycol 8:474-491

Contu M (1999) Entità nuove o interessanti del genere Cortinarius dalla Sardegna. Micologia e Vegetazione Mediterranea 14:33-40

Crous PW, Wingfield MJ, Burgess TI et al (2016) Fungal planet descriptions sheets: 469-557. Persoonia 37:218-403

Crous PW, Wingfield MJ, Burgess TI et al (2017) Fungal planet descriptions sheets: 558-624. Persoonia 38:240-384

Crous PW, Wingfield MJ, Lombard L et al (2019) Fungal planet descriptions sheets: 951-1041. Persoonia 43:223-425

de Carvalho PDS (2016) Studies of mycorrhizal associations in Cistaceae from a maritime pine forest: ecological and biotechnological approach. Master's degree Thesis, University of Coimbra: http://hdl. handle.net/10316/32174. Accessed 20 May 2020

De Crop E, Nuytinck J, Van de Putte K, Wisitrassameewong K, Hackel J, Stubbe D, Hyde KD, Roy M, Halling RE, Moreau P-A, Eberhardt U, Verbeken A (2017) A multi-gene phylogeny of Lactifluus (Basidiomycota, Russulales) translated into a new infrageneric classification of the genus. Persoonia 38:58-80

Demoly JP (2006) Notes taxonomiques, chorologiques et nouveautés nomenclaturales pour le genre Cistus L. élargi, incluant Halimium (Dunal) Spach (Cistaceae). Acta Botanica Gallica 153:309-323

Dentinger BT, Ammirati JF, Both EE, Desjardin DE, Halling RE, Henkel TW, Moreau PA, Nagasawa E, Soytong K, Taylor AF, Watling R, Moncalvo JM, McLaughlin DJ (2010) Molecular phylogenetics of porcini mushrooms (Boletus section Boletus). Mol Phylogenet Evol 57:1276-1292

Díez J, Anta B, Manjón JL, Honrubia M (2001) Genetic variation of Pisolithus isolates associated with native hosts and exotic eucalyptus in the western Mediterranean region. New Phytol 149:577-587

Dimou DM, Polemis E, Konstantinidis G, Kaounas V, Zervakis GI (2016) Diversity of macrofungi in the Greek islands of Lesvos and Agios Efstratios, NE Aegean Sea. Nova Hedwigia 102:439-475

Eberhardt U, Beker HJ, Vila J, Vesterholt J, Llimona X, Gadjieva R (2009) Hebeloma species associated with Cistus. Mycol Res 113: 153-162

Eyssartier G, Roux P (2011) Le guide des champignons-France et Europe. Belin, Paris

Fernandez-Brime S, Vila J, Ortega A (2014) Some new and interesting taxa of Cortinarius subgenus Phlegmacium from the European Mediterranean Basin. Mycologia 106:491-504

Galli R (1981) Uno Xerocomus sconosciuto in Sardegna. Natura e Funghi 2(4-5):28-31

Galli R (2013) I Boleti, 5th edn. Dalla Natura, Milano

Gardes M, Bruns TD (1993) ITS primers with specificity for basidiomycetes: application to the identification of mycorrhizae and rusts. Mol Ecol 2:113-118

Gelardi M (2010) Interessanti Boletaceae mediterranee rinvenute nel Lazio: Xerocomus ichnusanus e $X$. persicolor. Bolletino del Gruppo Micologico G. Bresadola 50 (1-3): 141-160

Gelardi M, Simonini G, Ercole E, Vizzini A (2014) Alessioporus and Pulchroboletus gen. nov. (Boletaceae, Boletineae), two novel genera for Xerocomus ichnusanus and X. roseoalbidus from the European Mediterranean basin: molecular and morphological evidence. Mycologia 106:1168-1187

Greuter W, Raus T (eds) (2000) Med-Checklist Notulae, 19. Willdenowia 30:229-243

Guzmán G, Ovrebo CL (2000) New observations on sclerodermataceous fungi. Mycologia 92:174-179

Guzmán B, Vargas P (2005) Systematics, character evolution, and biogeography of Cistus L. (Cistaceae) based on ITS, trnL-trnF, and matK sequences. Mol Phylogenet Evol 37:644-660 
Guzmán B, Vargas P (2009) Historical biogeography and character evolution of Cistaceae (Malvales) based on analysis of plastid rbcL and trnL-trnF sequences. Org Divers Evol 9:83-99

Heilmann-Clausen J, Verbeken A, Vesterholt J (1998) The genus Lactarius. In: Læssøe T, Petersen JH, Elborne SA (eds) Fungi of Northern Europe, 2. Svampetryk, Copenhagen, pp 1-287

Hofstetter V, Buyck B, Eyssartier G, Schnee S, Gindro K (2019) The unbearable lightness of sequence-based identification. Fungal Divers 96:243-284

Illice M, Tani O, Zuccherelli A (2011) Funghi velenosi e commestibili. Tipoarte Industrie Grafiche, Ozzano Emilia

Iotti M, Zambonelli A (2006) A quick and precise technique for identifying ectomycorrhizae by PCR. Mycol Res 110:60-65

Kirk PM, Cannon PF, David JC, Stalpers JA (eds) (2008) Ainsworth and Bisby's dictionary of the Fungi, 10th edn. CABI Publishing, Wallingford

Kuo M (2004) Scleroderma septentrionale. Retrieved from the mushroomexpert.com Web site: http://www.mushroomexpert.com/ scleroderma_septentrionale.html. Accessed 14 Apr 2020

Lalli G, Pacioni G (1992) Lactarius sect. Lactifluus and allied species. Mycotaxon 44:155-195

Lancellotti E, Iotti M, Zambonelli A, Franceschini A (2016) The Puberulum group sensu lato (whitish truffles). In: Zambonelli A, Iotti M, Murat C (eds) True Truffle (Tuber spp.) in the World. Soil Biology, 47: 105-124. Cham, Switzerland: Springer

Lebel T, Shaun Pennycook S, Matthew Barrett M (2018) Two new species of Pisolithus (Sclerodermataceae) from Australasia, and an assessment of the confused nomenclature of $P$. tinctorius. Phytotaxa 348:163-186

Leonardi M, Paolocci F, Rubini A, Simonini G, Pacioni G (2005) Assessment of inter- and intra-specific variability in the main species of Boletus edulis complex by ITS analysis. FEMS Microbiol Lett 243:411-416

Leonardi M, Iotti M, Oddis M, Lalli G, Pacioni G, Leonardi P, Maccherini S, Perini C, Salerni E, Zambonelli A (2013) Assessment of ectomycorrhizal fungal communities in the natural habitats of Tuber magnatum (Ascomycota, Pezizales). Mycorrhiza 23:349-358

Leonardi M, Comandini O, Rinaldi AC (2016) Peering into the Mediterranean black box: Lactifluus rugatus ectomycorrhizae on Cistus. IMA Fungus 7:275-284

Leonardi M, Neves MA, Comandini O, Rinaldi AC (2018) Scleroderma meridionale ectomycorrhizae on Halimium halimifolium: expanding the Mediterranean symbiotic repertoire. Symbiosis 76:199-208

Loizides M (2016) Macromycetes within Cistaceae-dominated ecosystems in Cyprus. Mycotaxon 131:255-256 (https://www. mycotaxon.com/resources/checklists/Loizides-v131-1-checklist. pdf). Accessed 12 Mar 2020

Martin F, Díez J, Dell D, Delaruelle C (2002) Phylogeography of the ectomycorrhizal Pisolithus species as inferred from nuclear ribosomal DNA ITS sequences. New Phytol 153:345-357

Martínez de Azagra Paredes A, Oria de Rueda Salguero JA, Martínez Zurimendi P (1998) Estudio sobre la potencialidad de los diferentes usos del bosque para la creación de empleo en el medio rural de Castilla y León. Iniciativa Comunitaria ADAPT. Fondo Social Europeo. Junta de Castilla y Léon. Universidad de Valladolid, Palencia

Martín-Pinto P, Vaquerizo H, Peñalver F, Olaizola J, Oria-de-Rueda JA (2006) Early effects of a wildfire on the diversity and production of fungal communities in Mediterranean vegetation types dominated by Cistus ladanifer and Pinus pinaster in Spain. For Ecol Manag 225:296-305

Molina R, Horton TR (2015) Mycorrhiza specificity: its role in the development and function of common mycelial networks. In: Horton TR (ed.) Mycorrhizal networks. Ecological studies, vol. 244, pp. 139. Dordrecht, The Netherlands: Springer
Moreau PA, Corriol G, Borgarino D, Auber P, Lavoise C, Richard F, Selosse M-A (2007a) Contribution à la connaissance des champignons de l'étage thermoméditerranéen Corse II. Bull Semestriel de de la Fédération des Assoc Mycologiques Méditerranéennes 31:931

Moreau PA, Corriol G, Borgarino D, Auber P, Lavoise C (2007b) Contribution à la connaissance des champignons de l'étage thermoméditerranéen Corse III. Bull Semestriel de de la Fédération des Assoc Mycologiques Méditerranéennes 31:33-84

Moreno-Arroyo B (ed) (2004) Inventario Micológico Básico de Andalucía. Consejería de Medio Ambiente, Junta de Andalucía, Córdoba

Moreno-Arroyo B, Gómez J, Pulido E (2005) Tesoros de nuestros montes. Trufas de Andalucía. Consejería de Medio Ambiente, Junta de Andalucía. Córdoba, Spain

Muñoz JA (2005) Boletus s.l. (excl. Xerocomus). Fungi Europaei 2. Alassio, Italy: Edizioni Candusso

Nuytinck J, Verbeken A, Leonardi M, Pacioni G, Rinaldi AC, Comandini $\mathrm{O}$ (2004) Characterization of Lactarius tesquorum ectomycorrhizae on Cistus sp., and molecular phylogeny of related European Lactarius taxa. Mycologia 96:272-282

Olaizola Suárez J, Cuesta Bachiller J, de la Parra PB, Oria de Rueda JA, Saiz Rojo A (2012) Gestión micológica forestal. Técnicas para mejorar las producciones de hongos silvestres comestibles en el País Vasco. Revista Foresta 55 (Especial País Vasco-Euskadi):4653

Olariaga I, Moreno G, Manjón JL, Salcedo I, Hofstetter V, Rodríguez D, Buyck B (2017) Cantharellus (Cantharellales, Basidiomycota) revisited in Europe through a multigene phylogeny. Fungal Divers 83:263-292

Oria-de-Rueda JA, Martin-Pinto P, Olaizola J (2005) Boletus edulis production in xerophilic and pirophitic shrubs of Cistus ladanifer and Halimium lasianthum in western Spain. In: Abstracts book of "IV International Workshop on Edible Mycorrhizal Mushrooms (IWEMM4)". Murcia (Spain) 28 Nov - 2 Dec 2005. Universidad de Murcia, Murcia, Spain, pp. 96

Oria-de-Rueda JA, Martín-Pinto P, Olaizola J (2008) Bolete productivity of cistaceous scrublands in Northwestern Spain. Econ Bot 62:323330

Oria-de-Rueda JA, Olaizola J, Fraile R, Martín-Pinto P (2009) Producción de Boletus asociados a matorrales de Cistáceas en el Noroeste de España. Fifth Congreso Forestal Español, Ávila

Ortega A, Bidaud A, Mahiques R (1997) Contribucion al estudio del genero Cortinarius en España peninsular. II parte. Cryptogam Mycol 18:227-231

Ortega A, Esteve-Raventós F, Navarro FB (2006) A re-evaluation of the Cortinarius scobinaceus and Cortinarius impolitus complex in the Mediterranean area. Mycologia 98:650-658

Page RG (2017) The Cistus \& Halimium Webpage. https://cistuspage. org.uk/. Accessed 4 June 2019

Persiani AM (2019) Alessioporus ichnusanus (errata version published in 2020). The IUCN Red List of Threatened Species 2019: e.T147144825A167285525. https://www.iucnredlist.org/species/ 147144825/167285525. Accessed 8 May 2020

Phosri C, Martín MP, Watling R, Jeppson M, Sihanonth P (2009) Molecular phylogeny and re-assessment of some Scleroderma spp. (Gasteromycetes). Anales del Jardín Botánico de Madrid 66S1:8391

Pierotti A (2002) Contributo alla conoscenza del genere Lactarius Pers. I. Il sottogenere Lactifluus (Burl.) Hesler \& A.H. Smith emend. Verb. Pagine di Micologia 18: 27-50

Pierotti A (2005) Contributo alla conoscenza del genere Lactarius. II Lactarius hepaticus. Bollettino del Gruppo Micologico G. Bresadola 48:47-56

Polemis E, Dimou DM, Tzanoudakis D, Zervakis GI (2012) Annotated checklist of Basidiomycota (subclass Agaricomycetidae) from the 
islands of Naxos and Amorgos (Cyclades, Greece). Ann Bot Fenn 49:145-161

Rinaldi AC, Comandini O, Kuyper TW (2008) Ectomycorrhizal fungal diversity: separating the wheat from the chaff. Fungal Divers 33:145

Rossi G, Montagnani C, Gargano D, Peruzzi L, Abeli T, Ravera S, Cogoni A, Fenu G, Magrini S, Gennai M, Foggi B, Wagensommer RP, Venturella G, Blasi C, Raimondo FM, Orsenigo S. (2013) Lista Rossa della Flora Italiana. 1. Policy Species e altre specie minacciate. Comitato Italiano IUCN e Ministero dell'Ambiente e della Tutela del Territorio e del Mare. Roma, Italy: Stamperia Romana

Rundel PW, Cowling RM (2013) Mediterranean-climate ecosystems. In: Levin SA (ed.) Encyclopedia of biodiversity, $2^{\text {nd }}$ ed.: $212-222$

Rusevska K, Karadelevi M, Phosri C, Dueñas M, Watling R, Martín MP (2014) Rechecking of the genus Scleroderma (Gasteromycetes) from Macedonia using barcoding approach. Turk J Bot 38:375-385

Santolamazza-Carbone S, Durán-Otero M, Calviño-Cancela M (2019) Context dependency, co-introductions, novel mutualisms, and host shifts shaped the ectomycorrhizal fungal communities of the alien tree Eucalyptus globulus. Sci Rep 9:7121

Smith SE, Read DJ (1997) Mycorrhizal symbiosis. Academic Press, San Diego

Soriano I (2008) Algunos tipos de cistáceas béticas y rifeñas de los herbarios BC, MA y MAF. Collectanea Botanica (Barcelona) 27: 29-35

Taudiere A, Munoz F, Lesne A, Monnet A-C, Bellanger J-M, Selosse MA, Moreau P-A, Richard F (2015) Beyond ectomycorrhizal bipartite networks: projected networks demonstrate contrasted patterns between early- and late-successional plants in Corsica. Front Plant Sci 6:881

Tedersoo L, Jairus T, Horton BM, Abarenkov K, Suvi T, Saar I, Kõljalg U (2008) Strong host preference of ectomycorrhizal fungi in a Tasmanian wet sclerophyll forest as revealed by DNA barcoding and taxon-specific primers. New Phytol 180:479-490
Teste FP, Jones MD, Dickie IA (2020) Dual-mycorrhizal plants: their ecology and relevance. New Phytol 225:1835-1851

Verbeken A, Van de Putte K, De Crop E (2012) New combinations in Lactifluus. 3. L. subgenera Lactifluus and Piperati. Mycotaxon 120: 443-450

Vidal JM, Vila J, Garcia F, Perez-Jarauta T (1997) Algunos hongos hipogeos de Castilla-León (España): Youngiomyces multiplex y Genea thaxterii, primeras citas para Europa. Revista Catalana de Micologia 20:85-98

Vidal JM, Calonge FD, Martín MP (2002) Macowanites ammophilus (Russulales), a new combination based on new evidences. Revista Catalana de Micologia 24:69-74

Vidal JM, Alvarado P, Loizides M, Konstantinidis G, Chachuła P, Mleczko P, Moreno G, Vizzini A, Krakhmalnyi M, Paz A, Cabero J, Kaounas V, Slavova M, Moreno-Arroyo B, Llistosella J (2019) A phylogenetic and taxonomic revision of sequestrate Russulaceae in Mediterranean and temperate Europe. Persoonia 42:127-185

Vizzini A, Angelini C, Ercole E (2015) Molecular confirmation of Gyroporus lacteus and typification of Boletus cyanescens. Phytotaxa 226:27-38

White TJ, Bruns T, Lee S, Taylor J (1990) Amplification and direct sequencing of fungal ribosomal RNA genes for phylogenetics. In: Innis MA, Gelfand DH, Sninsky JJ, White TJ (eds) PCR protocols: a guide to methods and applications. Academic Press, San Diego, pp 315-322

Zunzunegui M, Díaz Barradas MC, Aguilar F, Ain Lhout F, Clavijo A, García Novo F (2002) Growth response of Halimium halimifolium at four sites with different soil water availability regimes in two contrasted hydrological cycles. Plant Soil 247:271-281

Zunzunegui M, Ain-Lhout F, Díaz Barradas MC, Álvarez-Cansino LA, Esquivias MP, García Novo F (2009) Physiological, morphological and allocation plasticity of a semi-deciduous shrub. Acta Oecol 35: 370-379

Publisher's note Springer Nature remains neutral with regard to jurisdictional claims in published maps and institutional affiliations. 